\title{
The Role of Consumer Satisfaction in Mediating the Effect of Consumer Preference on Consumer Trust in Purchasing Cluster Housing in Jember
}

\author{
R. Alamsyah Sutantio \\ State Polytechnic of Jember \\ Jember, Indonesia \\ alamsyah@polije.ac.id
}

\author{
Siti Komariyah \\ Universitas Jember \\ Jember, Indonesia \\ kokom.feuj@gmail.com
}

\begin{abstract}
This paper is part of an ongoing dissertation that aims to analyze the mediating effect of consumer satisfaction in the relationship between consumer preference and consumer trust. The finding is a concept and is offering the model of the effect of consumer preference on consumer trust that has not been discovered by previous studies. The object of the study is the consumer purchasing the cluster housing. Data were collected using a proportional random sampling. Primary data were obtained through questionnaire and analyzed using GSCA, Generalized Structured Component Analysis. The results indicate that consumer preference has no significant effect on consumer trust to the housing developer. However, consumer satisfaction have an important role in mediating the effect of consumer preference on consumer trust towards the developer of cluster housing.
\end{abstract}

\section{Keywords-preference; satisfaction; trust}

\section{INTRODUCTION}

The growth of property business has increased after experiencing a fall in 2008 due to global economy crisis as the result of subprime mortgage crisis in the United States. High market demand for the property sector, particularly real estate, has increased the business competition. Moreover, the national economic growth also contributes to the growth in all regional areas in Indonesia, including Jember as one of the regions located in East Java Province. The fast growth of national real estate business also affects the growth of the same business in Jember.
The tight business competition in property sector creates more benefits for the consumers as they can choose among many options of the products. Consumers who are dissatisfied with the products will share their dissatisfaction with others. $54 \%$ to $70 \%$ of all customers who propose the complaints will repurchase the product and maintain the relationship with the company only if their complaints are managed well. The percentage will rise to $95 \%$ if the customers feel that the complaints are resolved quickly. Regarding to the complaint management, the satisfied customers will share their experience, in average, to five people, while the dissatisfied ones will share their bad experiences with 11 people (Kotler and Keller, 2012: 131).

Consumer satisfaction can be measured by using three models: (1) result satisfaction, (2) process satisfaction, and (3) total satisfaction (Kim, et al., 2008). Consumer satisfaction affects consumer trust towards the housing developer (Hess and Story, 2005; Zboja and Voorhess, 2006; Sahadev and Purani, 2008; Amin et al., 2013; Alfin et al., 2013; Chou et al., 2015). Trust is very important in the decision making process in the exchange relationships among the related parties (Stewart, 2003). There are 3 essential components of trust: good will, honesty, and ability to act (Walter et al., 2000).

Trust is a customer assessment to evaluate the extent to which the developer is trustworthy (Geven, 2000; Geven and Straub, 2003). To gain customer trust, the company should create effective communication, adopt customer's norms, and avoid negative assessments (Morgan and Hunt, 1994). The importance of customer trust is to maintain a 
long-term business relationship (Ndubisi, 2009; Walter and Ritter, 2003; Kennedy and Zagula, 2012: 5; Green 2006: 238).

One of the factors influencing consumers to buy a house is their preference of the house type. Consumer preference as a subjective assessment is measured from the utility of all commodities. Consumers are welcome to rank the commodities offered to them (Indarto, 2011). Some studies have proven that customer preference affects customer satisfaction (Aggarwal and Manjrekar, 2010; Abdullah et al., 2011). Consumer preference to buy a house is based on the design, brand, reputation, investment value, facilities, and accessibility (Rahadi et al., 2013). The preference can be determined by consumer mindset based on some reasons such as experiences and hereditary trust (Simamora, 2004: 87). Cluster housing has become one of the preferred housing types because of its exclusiveness, good infrastructure, and complete facilities (Vemby and Trikomara, 2014).

\section{METHODOLOGY}

This study is designed based on causal research since it aims to analyze the influence among variables (Cooper and Emory, 1995: 123). This is an explanatory research, thus it presents an exposition of causal relationships amongst the variables (Malhotra, 1999: 102). The population was the consumers who purchased the cluster housing from the developers in Jember. These developers are the members of the Association of Real Estate Indonesia (REI) in Jember, selling the cluster houses ranging from the price of 200 million to 500 million rupiahs per unit. 23 individuals were selected randomly from several cluster housing in Jember. The data were analyzed using descriptive analysis and inferential statistic of Generalized Structured Component Analysis or GSCA.

\section{RESULTS AND DISCUSSION}

\section{A. Validity and Reliability Test}

This research is valid and reliable as shown from the instrumental variables and the indicator with the Pearson correlation value above 0.3 and the Cronbach's alpha value above 0.6.

\section{B. Model Measurement}

Model measurement defines variable characteristics and its indicators as obtained by the line diagram construction. This research applies latent variable of consumer preference (X1) with the indicators of design, brand, reputation, reinvestment value, facilities and accessibility; latent variable of consumer satisfaction (Y1) with satisfaction indicators consist of results, process, and total satisfaction; and latent variable of consumer trust (Y2) with the indicators of good will, honesty, and action capability.

\section{Structural Model}

Structural model is evaluated by observing the relation between latent variables using GSCA and can be indicated by looking at the path coefficients.

\section{TABLE 1. PATH COEFFICIENTS}

\begin{tabular}{|l|c|c|}
\hline \multicolumn{3}{|c|}{ Path Coefficients } \\
\hline & Estimate & $\boldsymbol{C R}$ \\
\hline $\begin{array}{l}\text { Preference- } \\
\text { >Satisfaction }\end{array}$ & 0.593 & $3.88^{*}$ \\
\hline Preference->Trust & 0.201 & 0.83 \\
\hline Satisfaction-> Trust & 0.623 & $2.95^{*}$ \\
\hline
\end{tabular}

Table 1 indicates that the relation between latent variable of consumer preference with satisfaction and latent variable of consumer satisfaction with consumer trust are significant. On the contrary, the value of latent variable of consumer preference with latent variable of trust is not significant. This reveals that consumer preference in purchasing the cluster housing indicates distrust toward the housing developers.

\section{Measure of Fit}

Measurement model, structural model, and overall model are applied in the GSCA measure of fit analysis. 
Measure of Fit Measurement Model

\section{Convergent Validity}

Convergent validity on GSCA analysis shows correlation value between variable and the indicators. In the early phase of the research, the development of measurement scales, latent construct with the value of 0.5 until 0.6 is considered sufficient (Chin, 1998 in Aprilia and Ghozali, 2014).

\section{TABLE 2. CONVERGENT VALIDITY}

\begin{tabular}{|l|l|c|}
\hline \multicolumn{1}{|c|}{$\begin{array}{c}\text { Latent } \\
\text { Variables }\end{array}$} & Indicators & $\begin{array}{c}\text { Loading } \\
\text { Factor }\end{array}$ \\
\hline $\begin{array}{l}\text { Consumer } \\
\text { Preference } \\
\text { (X1) }\end{array}$ & Design & 0.738 \\
\cline { 2 - 3 } & Brand & 0.808 \\
\cline { 2 - 3 } & Reputation & 0.902 \\
\cline { 2 - 3 } & $\begin{array}{l}\text { Reinvestment } \\
\text { value }\end{array}$ & 0.502 \\
\cline { 2 - 3 } & Facilities & 0.579 \\
\hline $\begin{array}{l}\text { Consumer } \\
\text { Satisfaction } \\
\text { (Y1) }\end{array}$ & $\begin{array}{l}\text { Satisfaction of } \\
\text { results }\end{array}$ & 0.937 \\
\cline { 2 - 3 } & $\begin{array}{l}\text { Total } \\
\text { Satisfaction }\end{array}$ \\
\hline $\begin{array}{l}\text { Consumer } \\
\text { Trust } \\
\text { (Y2) }\end{array}$ & Good will & 0.911 \\
\cline { 2 - 3 } & Honesty & 0.856 \\
\cline { 2 - 3 } & $\begin{array}{l}\text { Capability to } \\
\text { act }\end{array}$ & 0.837 \\
\hline
\end{tabular}

As shown in Table 2, accessibility indicator for consumer preference variable (Y1) does not exist that means that it does not show the convergent validity because cluster housings are mostly located in the center area of Jember, making it as the less considered factor by the consumers. Satisfaction indicators for satisfaction variable (Y1) reveal no convergent validity. This is due to the consumer satisfaction in purchasing the cluster housing which is determined by their total satisfaction without considering the buying process.

\section{Discriminant validity}

Discriminant validity of reflective measurement model is applied by comparing the square root value from the AVE (average variance extracted) of each latent variable with the correlation amongst variables in the models.
TABLE 3. DISCRIMINANT VALIDITY VARIABLE

\begin{tabular}{|l|c|}
\hline \multicolumn{1}{|c|}{ Variable } & AVE \\
\hline $\begin{array}{l}\text { Consumer } \\
\text { Preference }\end{array}$ & 0.520 \\
\hline $\begin{array}{l}\text { Consumer } \\
\text { Satisfaction }\end{array}$ & 0.853 \\
\hline Consumer Trust & 0.673 \\
\hline
\end{tabular}

\section{Internal concistency reliability}

A group of indicators measuring variables has a good consistency of internal reliability if the alpha is $\geq 0.6$, but it is not an absolute standard.

\section{TABLE 4. INTERNAL CONSISTENCY} RELIABILITY

\begin{tabular}{|l|c|c|}
\hline \multicolumn{1}{|c|}{ Variable } & Alpha & Cut Off \\
\hline $\begin{array}{l}\text { Consumer } \\
\text { Preference }\end{array}$ & 0.742 & 0.6 \\
\hline $\begin{array}{l}\text { Consumer } \\
\text { Satisfaction }\end{array}$ & 0.825 & 0.6 \\
\hline Consumer Trust & 0.757 & 0.6 \\
\hline
\end{tabular}

From the Table 4, it can be concluded that the variables of consumer preference, consumer satisfaction, and consumer trust indicate the alpha value $\geq 0.6$ that shows that the three instruments in this research indicate internal consistency reliability.

\section{E. Model Fit}

Model fit in GSCA analysis is employed to determine the appropriate model used in this research.

\section{Measure of Overall Model Fit}

A measure of overal model fit is employed to determine the overall model used in the research. This can be observed from the value of GFI and SRMR. The model is considered in a good fit when the result of SRMR is $<0.08$ or close to zero value. The research finds GFI value is $>0.90$ close to 1 . Meanwhile, SRMR value is of 0.115 and GFI value is of 0.992. This then demonstrates that the model of the research is in a good fit. 
TABLE 5. MODEL FIT

\begin{tabular}{|c|c|}
\hline \multicolumn{2}{|c|}{ Model Fit } \\
\hline FIT & 0.558 \\
\hline AFIT & 0.509 \\
\hline GFI & 0.992 \\
\hline SRMR & 0.115 \\
\hline NPAR & 23 \\
\hline
\end{tabular}

\section{F. $t$ Test}

Based on the $t$ test results, it is proved that the consumer preference variable (X) does not significantly affect consumer trust (Y2). However, consumer preference variable $(\mathrm{X})$ affects consumer trust (Y2) through consumer satisfaction (Y1).

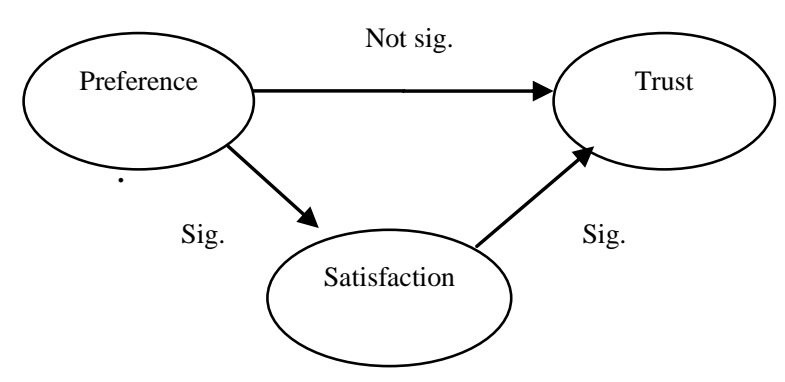

FIGURE. 1. RESEARCH MODEL

\section{CONCLUSION}

House is a human basic need in improving their dignity, pride, and life quality. It is also a reflection for the individual as an effort to increase their standard of living, character building, and nation personality. Consumers with high purchasing power will have high preferences in buying a house. Cluster housing is one type of housings that offers various facilities. Consumer preference is based on design, brand, reputation, reinvestment value, facilities, and accessibility. There are large numbers of developers that put their greatest effort to meet consumer preferences. This effort is aimed to gain consumer trust.

Consumer preference does not directly affect consumer trust toward the housing developer. This is due to the fact that consumers often rely on their experiences and also references from other consumers in buying a cluster house. In making a purchase decision, consumers also refer to some sources of information related to the problems in the process of handing over the house from the developer, e.g., delays, certification, construction quality, misleading information from the salesperson, social and public facilities, and the problem of additional costs. These conditions lead consumers to a decision that they will not buy the house unless the physical construction of the house is finished.

Consumer satisfaction plays an important role in the process of purchasing cluster house. This means that the consumers will not trust the developers before they can see the real physical condition of the house. Therefore, the developer should pay serious attention to the various components that can satisfy the consumers such as:

1) Providing a ready-to-occupied cluster housing that is in accordance with the specifications offered;

2) Delivering better administrative services;

3) Complying what have been promised to the consumers regarding to the provision of all of the supporting facilities.

If consumer satisfaction is met then it will raise their trust to the developer. Consumer trust will give good impact to the business because consumers tend to be loyal and they will also give reference to other consumers to purchase the product.

\section{ACKNOWLEDGMENT}

The authors would like to thank to Prof. Dr. R. Andi Sularso, Dr. Bambang Irawan, and Dr. Moh. Dimyati, and State Polytechnic of Jember for the help and support in finishing this paper. The authors also thank Directorate of Research and Community Services of the Ministry of Research, Technology, and Higher Education of Indonesia for the financial support for this paper. 


\section{REFERENCES}

[1] Abdullah, Firdaus; Zainoren, Abg, Abdurahman, Abg, and Hamali, Jamil, Managing Customer Preference for the Foodservice Industry, International Journal of Innovation, Management and Technology, Vol. 2, No. 6, December, pp. 525533. 2011

[2] Adma, Tri Adi Nugroho, Analysis of Factors Affecting Communities In choosing Houses Type Cluster in Gresik, Civil Engineering, Vol 3 Number 3, pp. 12-19, 2015.

[3] Alfin, Rita; Alhabsji, Taher; Nimran, Umar; dan Suharyono, 2013, Effect of Service Quality and Product Quality To Corporate Image, Customer's Satisfaction and Customer's Trust, IOSR Journal of Business and Management (IOSR-JBM) Vol. 9, Issue 6, pp. 01-09. Maret - April 2013.

[4] Amin, Muslim; Isa, Zaidi dan Fontaine, Rodrigue, Islamic banks Contrasting the drivers of customer satisfaction on image, trust, and loyạlty of Muslim and non-Muslim customers in Malaysia, International Journal of Bank Marketing, Vol. 31 Iss 2 pp. $79-97.2013$.

[5] Aggarwal, Artee; Manjrekar, Pradip, Factors affecting customers' preference and satisfaction towards men's apparel retail formats: a study of North Central Mumbai, ASBM Journal of Management, Vol. 3, nomor 1\&2, pp. 47-55. 2010.

[6] Aprilia, Karlina, Kusumadewi; Ghozali, Imam, Generalized Structured Component Analysis (GesCA), Component-Based Structural Equation Model, Semarang: Diponegoro University Publishers, 2014.

[7] Chou, Shihyu.; Chen, Chi-Wen dan Lin, Jiun-You, Female online shoppers Examining the mediating roles of e-satisfaction and e-trust on e-loyalty development, Internet Research, Vol. 25 Iss 4 pp. $542-561.2015$.

[8] Cooper, Donald R., and Emory, William, Business Reseach Methods, Fifth Edition, USA: Irwin R.D., Inc., 1995.

[9] Geven, D. E-Commerce, The rile of familiarity and Trust, Journal of Marketing, Omega 28, pp 725- 737. 2000.

[10] Geven. D. and D. W. Straub, Managing user Trust in b2c e-Services, e-Service Journal, Vol. 5, pp 7-24. 2003.

[11] Hawkins, David 1., Mothersbough and Best, Roger J., Consumer Behavior: Building Marketing Strategy, (10 th. Edition), New York: MCGrawHill/Irwin, 2007.

[12] Hess, Jeff., and Story, John, Trust-Based Commitment: Multidimensional Consumer-Brand Relationships. Journal of Consumer Marketing, vol., 22/6, pp 313-322. 2005.

[13] Indarto, R. P., Analysis of Consumer Preferences Against Bundling GSM cards with smartphones, Thesis, Jakarta: University of Indonesia, 2011.

[14] Kim, Changsu; Zhao, Weihong and Yang, Kyung Hoon, An Empirical Study on then Integrater Framework of e-CRM in Online Shopping: Value, Satisfaction and Trust Based on Customers Perspective, Journal of Electronic Commerce in Organizations Vol. 6, No. 3, pp. 1-19, 2008.
[15] Kotler, Philip and Keller, Kevin Lane, Marketing Management, Twelfth Edition, New Jersey: Pearson Education, Inc., Upper Saddle River. 2012.

[16] Malhotra, Naresh K., Marketing Research: An Applied Orientation, New Jersey: Prentice Hall, Inc., 1999.

[17] Parasuraman, A., Zeithaml, V.A., and Berry, L. L, The Behavioral Consequences of Service Quality. Journal of Marketing.Vol.60, pp. 55-68, 1996.

[18] Rahadi, Raden Aswin; Wiryonoa, Sudarso Kaderi; Koesrindartotoa, Deddy P. and Syamwil, Indra Budiman, Attributes Influencing Housing Product Value and Price in Jakarta Metropolitan Region, Journal of Social and Behavioral Sciences, Vol. 101, pp $368-378,2013$.

[19] Sahadev, Sunil, and Purani, Keyoor, Modelling the consequences of e-service quality, Marketing Intelligence \& Planning, Journal of Marketing, Vol. 26 Iss 6 pp. $605-620$. 2008 .

[20] Simamora, Bilson, Marketing Research: Philosophy, Theory and Applications, Jakarta: PT. Gramedia Pustaka Utama, 2004.

[21] Solimun, Training, Strengthening Research Methodology: General Structural Component Analysis-GSCA, Malang: Faculty of Mathematics and Statistics Studies Program Brawijaya University Press, 2013.

[22] Stewart. K., Trust Transfer on The World Wide Web, Organization Science, Vol.14, No. 1, pp. 5-17, 2003.

[23] Vemby, Mailino; Trikomara, Iriana Rian, Analisis Pengaruh Biaya telah dipakai Terhadap Harga Jual Rumah Pada Perumahan Interest Rate Cluster Di Kota Pekanbaru (Studi Kasus: Perumahan Harmoni Residence), Jurnal Pemasaran, Vol 1, No.1. pp. 3143. 2014

[24] Walter, Achim.; Thilo A., Mueller and Helfert, Gabriele, The Impact of Satisfaction, Trust and Considerations and Empirical Results, Germany: University of Karlsruhe, IBU, P.O. Box 6980, D76128 Karlsruhe, 2000.

[25] Zboja, James J., and Voorhees, Clay M., The impact of brand trust and satisfaction on retailer repurchase intentions, Journal of Services Marketing, Vol. 20, No.6, pp. 381 - 390. 2006. 